\title{
BEL OLID
}

"Nothing Will Have Taken Place but the Place" (fiction)

Translated by Bethan Cunningham 

The street has changed again. I go outside and find that, once more, the little shop on the corner isn't the little shop on the corner anymore. That everyone looks foreign, which leads me to suspect that I'm the foreign one.

Just for my own amusement, and maybe also to distract myself from my impending madness, I ask a six-foot, blonde, female passerby for the time, and she stops for a moment. And I do it in Catalan, knowing she doesn't speak Catalan, for the simple, immature pleasure of watching her think for a second before telling me she doesn't understand in a kind of German I can't situate.

I even let myself get excited for a minute and hope she's from Zurich. I've never been to Zurich and I'd love to be there right now, to have ended up there via this kind of time or space machine that my life has been lately.

But I put my hand in my pocket and retrieve three euros fifty. No Swiss francs, so I must be in the EU. For now, I'll have to resign myself to not seeing any lakes or flower sellers in squares or anything else I've always imagined Zurich must have and that, for now, I won't take in.

I must admit, at the start it was hard not to go mad, even though the first few times were simpler. I can remember perfectly the stupefying realization that I'd gone to bed at home in Barcelona and woken up, unknowingly, in Mataró: not even twenty-five miles away, just half an hour on the train, tracing, with a finger on the window, the curve of the coast and the occasional port. But, even so, it was such a forceful jolt to the laws of nature that I considered anything and everything.

I imagined a non-existent drinking session, a pill hidden in a gin and tonic that I didn't drink, a joke in poor taste from the friend who didn't bring me home.

But nothing would rid me of the irrefutable weight of having woken up at home, of having smelled my soap in the shower, of having found the coffee and sugar and magdalenes without thinking about it, in their place, in the yellow kitchen cupboard. Quite simply, when I went down the stairs and out into the street, there was no old man with a white moustache and Lleida accent in the little shop on the corner, and the traffic lights had moved, and the twenty-five steps to the metro stop were futile, as there was now no giant $\mathrm{M}$, or steps, or elevator.

Now I barely bat an eyelid when, more and more often, I leave the house and find myself far away. I have a second breakfast in front of a 
newspaper that gives me clues as to where I am. I find the airport, or the train or bus station and I pay for a ticket with money that I didn't put in my pocket.

But that first time, walking disoriented towards the beach looking for the station, all of it fazed me. A while later, when I arrived at my front door, I felt afraid of opening it and not finding everything in its place. And for weeks afterward, I panicked that I might go out into the street and find a different landscape of unknown spots and unfamiliar smells. But no, nothing, nothing at all, days and days with the same buildings of the same colors.

In the end, it seems everything is overwhelmed by the sheer weight of everyday life: working at the computer, Sunday lunch at your intimidating auntie's house, buying broccoli and toilet paper and socks. Routine comes to the rescue once again. And even the most incomprehensible situation becomes shrouded in a dreamlike, hallucinatory cloud, like a fantasy so obscene that it must be relegated right to the back of the mind, like a thought left unshared because it would worry everyone.

Until, one day, after months of going out every day at ten to buy a newspaper after tending to various agencies' and editors' emergencies, I once again found myself elsewhere in the world. The second time, pointlessly, it occurred to me to turn around and climb back up the stairs to the door that bore my name. Then came that cold sweat when I saw that the stairs were no longer my stairs and that the name on flat number 2 on the first floor was not my name. I went back down and, shrugging my shoulders, faced up to the fact that this bridge rang a bell, that I'd had breakfast in this café before, that I was in Girona, which was lucky, as I knew where the train station was and it wasn't too far away, so at least I wasn't dying with fear. There are little pleasures to be found within the most absurd absurdity of the most ludicrous moments ever experienced.

With every new journey, I'm slowly feeling more and more of a sense of resignation. I've learned to be surprised by the calm flatness of Amsterdam, the striking light of Naples, the freezing rain of Glasgow, the dazzling cold of Paris. I've seen capital cities and remote villages. Now I'm not in as much of a rush to go home. I amuse myself in museums or go for a walk in the countryside. I wait patiently for trains and planes. I buy books and read them in the park. Suddenly my life of language schools and satellite TV makes sense; it becomes obvious why I 
chose a career in translation. In quiet periods, when all the editors are in Bologna or the agencies forget I'm here, I study Russian and read travel guides about Japan. For now, the only noticeable pattern is that I appear farther away from my world every time; I make more connections on my journey home every time.

Today, before getting in a taxi to go to the airport, I enter a quiet café and pick a table at random, next to the window, in the pale sun of early summer, opposite a man who is stirring his coffee and then, in order to look at me, raises his eyes from a guide that says "Köln" in yellow letters. I must be in Cologne, then. Or maybe not: maybe he's a Berliner planning a trip to the south. I don't know. I don't know anything anymore, and I don't care. Like I don't care about the waitress's face like a slapped ass, which makes the man's lips seem even sweeter, her unnecessarily bitter voice when she asks if I want to order, which makes his gaze even sweeter, her obvious bad mood when she slams my tea down in front of me, which makes his gait even sweeter when he gets up and comes towards me and asks, in an obviously Irish brand of English, if I mind if he sits next to me.

And he looks at me with a shadow as deep and dark as my own, with such deep doubt invading every wrinkle on his forehead that I don't need to ask where we are to know that he's lost too, that he can't get his bearings from his guide, that, like I've done so many times before, he's trying to find himself, to take refuge in the perpendicular peace of streets on maps, of spaces with names that mean something, with names you can repeat to strangers so that they nod and smile and tell you where you're going or where you're coming from, if you're lucky.

So yes, he looks at me. And the shadow swallows me up and frightens me and shakes me, and all I can do is leave before he opens his mouth, before he tells me his story, which is as unclear and inexplicable as my own. And I flee from sharing this irrationality that, until now, was bearable just because it was my own, exclusive, latent. Because it didn't happen to anyone else. Because, if you don't talk about it, the incomprehensible simply doesn't exist.

I get up and fly off through deserted streets, fly with my hair in the wind. I run aimlessly, run without hearing cars or birds, run until I'm breathless, and even when breathless I keep running. And I finally stop, at the front door on a street that's the same street, that's my street this time. Surprisingly, I climb the same old steps and find them cold, and 
read a name on the door that I know is my own but seems alien to me. I'm scared it will be in finding myself that I lose myself.

But I stick my hand in my pocket and find keys that fit in the lock effortlessly, as though five minutes ago I was actually in a café in Eixample and not in some neighborhood in some corner of Germany opposite an Irishman, as though home had never moved from its place, as though I'd made all this up.

And the most worrying thing is that it's easy for me to accept this, to open the door, go to the kitchen, make coffee. And sit next to the window and wait for the bell to ring and for it to be him, to invite him in and to spend the day telling each other about impossible journeys to unspecific countries. To liberate tears with words, fear with caresses, helplessness with gestures. To erase the irrationality of life with the irrationality of pleasure.

And there's that vertigo again when, in the morning, in front of the unmade bed, I'm not sure whether I'm at my house or his. 